\title{
DISPLAY INSTAGRAM @STARBUCKSINDONESIA : STIMULUS MASYARAKAT KONSUMSI PADA GERAI STARBUCKS CENTRAL PARK MALL
}

\author{
INSTAGRAM DISPLAY @STARBUCKSINDONESIA : \\ CONSUMPTION SOCIETY STIMULI ON STARBUCKS CENTRAL \\ PARK MALL
}

\author{
Meisy Efna Prisylia \\ Institut Komunikasi dan Bisnis The London School of Public Relations Jakarta \\ Email : prisyliameisy@gmail.com
}

\begin{abstract}
This research sees social media Instagram @starbucksindonesia as a display in attracting people to buy products. The theory used in this research is the Consumption Society theory put forward by Baudrillard. The method used is an interpretative qualitative research method with Baudrillard's post-modern approach. Data collection was carried out with literature studies and text observations on Starbucks Indonesia Instagram social media. The results showed that our society has now become a consumptive society with the internet as a new medium for delivering messages, especially displays that attract customers' attention. With the development of new media, the activities of our society are now closely related to social media, especially Instagram, which currently has more than 61 million active users by the end of November 2019. People who follow Instagram Indonesia Instagram accounts can get the information provided and interested and want to buy products that are being offered especially in certain seasons.
\end{abstract}

Keywords: Instagram; consumption society; mass media; social media; display

\begin{abstract}
ABSTRAK
Penelitian ini melihat media sosial instagram @Starbucks inndonesia sebagai display dalam menarik masyarakat untuk membeli produk. Teori yang digunakan pada penelitian ini adalah teori Masyarakat Konsumsi yang dikemukakan oleh Baudrillard. Metode yang digunakan adalah metode penelitian kualitatif interpretatif dengan pendekatan post-modern Baudrillard. Pengumpulan data dilakukan dengan studi literatur dan observasi teks pada media sosial instagram Starbucks Indonesia. Hasil penelitian menunjukkan bahwa masyarakat kita sekarang ini sudah menjadi masyarakat yang konsumtif dengan adanya internet
\end{abstract}

ISSN 2338 - 0861 (cetak); e-ISSN 2621 - 8712 (online)

website : http://spektrum.stikosa-aws.ac.id 
sebagai media baru penyampai pesan terutama display yang menarik perhatian pelanggan. Adanya perkembangan media baru, aktivitas masyarakat kita kini tidak lepas dari media sosial khususnya Instagram yang saat ini mempunyai lebih dari 61 juta pengguna aktif hingga akhir November 2019. Masyarakat yang memfollow akun instagram Starbucks Indonesia, bisa mendapatkan informasi yang diberikan dan tertarik dan ingin membeli produk yang sedang ditawarkan terutama pada season tertentu.

\section{Kata Kunci: Instagram; masyarakat konsumsi; media massa; media sosial; display}

\section{PENDAHULUAN}

Globalisasi menyebabkan mudahnya budaya asing masuk ke Indonesia. Hal ini juga mempengaruhi perkembangan media yang akan berpengaruh juga terhadap gaya hidup masyarakat modern saat ini, biasa disebut modernisasi. Modernisasi ditandai oleh berubahnya sikap dan perilaku, pengeluaran (belanja) pendidikan, revolusi pengetahuan melalui sarana komunikasi, industrialisasi, urbanisasi, sekularisasi, dan teknologi yang maju (Maslow, 1991). Perubahan ini membuat teknologi komunikasi sangat penting dalam masyarakat informasi karena dengan teknologi, memudahkan orang untuk bertukar informasi dengan orang lain melalui sistem komunikasi yang berbasis komputer. Sistem komunikasi tersebut dinamakan sebagai teknologi komunikasi baru, media baru, atau komunikasi interaktif. Media baru cenderung dihubungkan dengan internet, karena internet dianggap meliputi banyak hal yang tidak bisa dilakukan media cetak dan elektronik.

Keberadaan sarana komunikasi ini memberikan dampak yang signifikan di berbagai bidang seperti sosial, ekonomi, pendidikan, dan bidang-bidang lainnya. Komunikasi tidak hanya dilakukan secara fisik, tetapi dapat dilakukan dengan berbagai media sosial seperti dunia maya. Salah satu penemuan media komunikasi yang super canggih yaitu internet.
Kelebihan internet itu sendiri yaitu penyedia jaringan data yang berguna untuk komunikasi dan memiliki kecepatan dalam pengiriman dan menerima sebuah informasi. Internet juga melahirkan banyak jejaring sosial dengan sebuah media komunikasi tanpa menggunakan biaya karena dilakukan secara online (Hafied, 2007).

Dengan pesatnya perkembangan ini, telah memberikan dampak terhadap situsitus komunikasi, dari sekedar email dan chatting, menjadi media sosial atau jejaring sosial seperti Facebook, Twitter, Line Official Account, Instagram, Path, Whatsapp dan Snapchat. Salah satu media sosial yang sedang banyak digunakan oleh penggunaan gadget saat ini adalah Instagram. Instagram adalah sebuah aplikasi berbagi foto yang memungkinkan pengguna mengambil foto, menerapkan filter digital, dan membagikannya ke berbagai layanan jejaring sosial, termasuk milik Instagram sendiri. Instagram berdiri pada tahun 2010 dan didirikan oleh Kevin Systrom dan Mike Krieger (Juju \& Sulianta, 2010).

Instagram bukanlah lagi hanya sebuah aplikasi berbagi foto pribadi tetapi juga menjadi tempat berbisnis yang menjanjikan. Kita bisa menemukan banyak hal yang kita cari di Instagram seperti baju, aksesoris, kecantikan dan masih banyak lainnya. Banyak para pebisnis memanfaatkan Instagram menjadi tempat display untuk mempromosikan produk yang mereka jual. Bukan hanya menjadikannya 
tempat promosi tapi juga membuktikan eksistensi sebuah perusahaan atau organisasi yang sudah dibangun.

Menurut Sopiah dan Syihabuddin (2010) "Display adalah usaha yang dilakukan untuk menata barang yang mengarah pembeli agar tertarik untuk melihat dan memutuskan untuk membelinya". Sedangkan menurut Gerard J Tellis "Display ialah usaha mendorong perhatian dan minat konsumen pada toko atau mendorong keinginan membeli melalui daya tarik penglihatan langsung". Maka dari itu, Display adalah usaha untuk mempromosikan suatu barang atau jasa agar menarik untuk dibeli.

Hal ini dimanfaatkan oleh Starbucks Indonesia dalam mempromosikan produk yang mereka jual. Akun Instagram Starbucks Indonesia saat ini sudah mempunyai 1,1 juta followers ditinjau per tanggal 14 Februari 2020. Dalam Instagram tersebut juga tertera link yang biasanya akan terhubung dengan web server yang berisi penawaran-penawaran khusus dan informasi lainnya. Starbucks merupakan perusahaan penjual kopi asal Amerika yang sudah berdiri sejak tahun 1971 di Seattle dan masuk ke Indonesia pada tahun 2002. Starbucks Amerika sendiri telah mempunyai akun Instagram resmi pada tahun 2010 dan pada tahun 2012 Starbucks Indonesia membuka akun Instagram-nya (Starbucks Coffee).

Starbucks Indonesia melakukan komunikasi massa yang bersifat persuasif menggunakan medium media sosial terkhusus Instagram untuk menarik minat beli masyarakat terhadap produk yang mereka pasarkan, serta informasi terkini mengenai pembukaan store baru atau adanya kegiatan community development yang baru pertama kali dilakukan tahun 2020. Secara tidak langsung hal ini menyebabkan perilaku konsumtif masyarakat yang tadinya tidak pernah minum kopi tetapi karena Starbucks mempunyai penawaran khusus seperti; 'buy one get one', 'family treats', 'tumbler day', 'Monday treats' hingga tampilan store yang nyaman yang bisa membuat orang mau datang mengantri hanya untuk pembelian dengan penawaran tertentu ataupun menggunakan aplikasi online (Starbucks Indonesia). Pemberian double reward bagi para member yang telah bergabung setiap tanggal tertentu setiap bulan, dan keuntungan lainnya jika menggunakan kartu kredit dalam bertransaksi menjadikan Starbucks salah satu kedai kopi yang favorite dari kalangan remaja hingga orang kantoran.

Begitu juga dengan penjualan merchandise berupa Official Tumbler yang diadakan tanggal 22 setiap bulannya dengan promo tumbler day. Dalam tumbler day tersebut biasanya konsumen yang membeli produk Starbucks dengan menggunakan official tumbler Starbucks akan mendapatkan potongan harga sebesar 50 persen karena sudah ikut mendukung dalam mengurangi penggunaan plastik dan berlaku di seluruh gerai Starbucks Indonesia. Disaat itu biasanya Starbucks akan membuat sebuah 'reminder' yang mengingatkan bahwa jangan lupa bawa tumbler-mu karena akan ada potongan harga, membuat yang tadinya tidak ingin mampir ke Starbucks menjadi tertarik untuk datang. Dari contoh tersebut, menyatakan bahwa Instagram dapat mempengaruhi perilaku konsumtif masyarakat karena melihat foto atau instastory yang dibagikan di akun Instagram Starbucks Indonesia. Design tempat yang nyaman bagi pengunjung juga salah satu faktor kenapa banyak orang lebih suka bertemu untuk meeting bersama client di Starbucks atau hanya sekedar nongkrong mengisi waktu luang sambil menikmati minuman (yang tidak harus selalu kopi) dan makanan. Hal ini seakan sudah menjadi gaya hidup masyarakat saat ini.

Dalam menyambut hari kasih sayang yang jatuh pada tanggal 14 Februari atau yang biasa disebut Valentine's Day yang identik dengan berpasangan, maka Starbucks Indonesia mengerluarkan beberapa promo dengan judul 'One For You, One To Share' dengan hashtag SayItWithSbux (Starbucks Indonesia). Dalam promo ini, seluruh gerai Starbucks 
yang ada di Indonesia memberikan promo semacam buy 1 get 1 free setiap pembelian minuman apapun berukuran Tall. Pada hari itu juga, Starbucks akan mempunyai desain gelas khusus hari kasih sayang. Starbucks juga mengeluarkan official tumbler dan Starbucks card valentine's edition yang tentunya menjadi tawaran menarik khusus pada tanggal itu saja. Untuk mendapatkan promo minuman tersebut maka, para konsumen harus sudah memfollow akun Instargam dari Starbucks Indonesia dan mengakses link kupon yang tersedia di bio akun Starbucks yang aka divalidasi saat di kasir. Kupon ini berlaku sekali untuk satu akun Instagram. Tentu sebelum acara ini berlangsung maka Starbucks Indonesia sudah mulai memberikan petunjuk disetiap posting-an, yang mengacu pada ketertarikan pada acara berikutnya. Starbucks mulai mengunggah hal tersebut diakhir bulan Januari setelah acara edisi Tahun Baru Imlek selesai. Untuk pembelian tumbler dan Starbucks card akan tersedia selama bulan Februari 2020 selama persediaan masih ada. Hal ini mendapat respon baik dari para followers yang sudah tidak sabar untuk menunggu kejutankejutan berikutnya.

Manusia hidup dengan kebutuhan inilah yang akan menjadi satu elemen penting motivasi yang mengarahkan individu untuk berperilaku konsumtif. Tak jarang kemudian gaya hidup ini mendasari perilaku konsumen. Hal ini dimanfaatkan oleh produsen dan pemasar untuk memasarkan bisnisnya, seperti fenomena Starbucks Indonesia menggunakan media sosial sebagai display untuk promosi terutama media sosial Instagram yang berpengaruh pada perilaku konsumtif. Berbagai macam cara promosi dilakukan seperti mendapatkan voucher jika mengikuti akun, special price untuk produk tertentu, potongan harga untuk yang menyukai unggahan foto tertentu hingga mengumumkan produk baru yang bisa di coba di gerai-gerai tertentu.

Dari penjabaran diatas penelitian ini bertujuan untuk melihat bagaimana media sosial Starbucks Indonesia terutama
Instagram sebagai display dalam menarik masyarakat untuk membeli produk Starbucks . Dalam penelitian ini yang menjadi fokus pembahasan adalah berperilaku konsumtif masyarakat terhadap produk Starbucks Indonesia yang distimulus dari display media sosial Instagram milik Starbucks Indonesia dan menjadikan konsumen tidak lagi melakukan konsumsi produk ini atas dasar kebutuhan tetapi gaya hidup (Starbucks Indonesia). Oleh karena itu dalam penelitian ini menggunakan teori masyarakat konsumsi oleh Jean P Baudrillard.

Perubahan yang terjadi pada para perilaku konsumsi kopi tidak terlepas dari pengaruh perkembangan globalisasi yang membuat masyarakat berperilaku konsumtif. Ini akan menghasilkan berbagai perubahan dalam interpretasi perilaku konsumsi kopi di masyarakat Semarang. Tujuan penelitian adalah untuk mengetahui perilaku konsumsi kopi, budaya masyarakat konsumsi, dan tragedi budaya konsumsi kopi di kalangan peminum kopi di warung kopi Kota Semarang. Teori yang digunakan dalam penelitian ini adalah teori masyarakat konsumsi Jean P Baudrillard, teori budaya modern Georg Simmel, dan teori kelas reaksi Thorstein Veblen. Penelitian ini menggunakan pendekatan fenomenologis, yang bertujuan untuk mengeksplorasi motif dan makna tindakan mendalam terkait perilaku mengkonsumsi kopi sebagai budaya masyarakat konsumen. Pengumpulan data dilakukan dengan menggunakan observasi langsung dan wawancara mendalam. Hasil penelitian menunjukkan bahwa interpretasi perilaku konsumsi kopi di masyarakat Semarang telah berubah (Solikatun, Kartono, Demartoto, 2015).

Perilaku konsumsi kopi dapat dilihat dari aktor atau peminum kopi, aktivitas yang dilakukan, penampilan mereka, alasan konsumsi kopi, dan tempat konsumsi kopi. Dalam perilaku mengkonsumsi kopi, tidak hanya secangkir kopi dikonsumsi tetapi peminum kopi juga mengonsumi prestise, status sosial, kesan elegan dan eksklusif, dan gaya hidup masyarakat modern. Dalam hal

ISSN 2338 - 0861 (cetak); e-ISSN 2621 - 8712 (online)

website : http://spektrum.stikosa-aws.ac.id 
ini, apa yang dibeli dan dikonsumsi tidak lebih dari tanda-tanda yang melekat pada objek konsumsi. Perilaku mengkonsumsi kopi dibuat untuk mengikuti gaya hidup masyarakat modern yang menekankan pada prestige, meskipun peminum kopi tahu bahwa apa yang mereka konsumsi kadangkadang tidak seperti apa yang mereka inginkan, misalnya rasa minuman kopi yang disajikan terasa pahit karena berasal dari biji kopi pilihan. Perbedaan interpretasi pada perilaku konsumsi pada kopi antara satu peminum kopi dan yang lain menyebabkan tipifikasi peminum kopi. Tipifikasi peminum kopi dalam menafsirkan perilaku konsumsi kopi dibagi menjadi dua yaitu peminum kopi modern dan tertutup (Putlia, 2018).

\section{Display}

Untuk dapat menyuguhkan display yang menarik, perlu perancangan yang optimal. Selain itu, untuk memperolah hasil yang baik memerlukan designer yang profesional, sumber data yang menguasai tentang produk dan spesifikasinya.

Display adalah suatu cara penataan produk, terutama produk barang yang diterapkan oleh perusahaan tertentu dengan tujuan untuk menarik minat konsumen. Menurut Wiliam J. Shultz yang dikutip dari Buchari, "Display consist of simulating customer attention and interest in a product or a store, and desire to buy the product or patronize the store, through direct visual appeal". Display adalah suatu cara mendorong perhatian dan minat konsumen pada toko atau barang dan mendorong keinginan membeli melalui daya tarik penglihatan langsung (direct visual appeal). Display digunakan untuk melalukan promosi penjualan (Buchari, 2007).

Tujuan dari display adalah (1) Attention and interest customer: menarik perhatian pembeli dilakukan dengan cara menggunakan warna-warna, lampu-lampu dan sebagainya. (2) Desire and action customer: menimbulkan kenginan memiliki barang-barang yang dipamerkan di toko tersebut, setelah masuk ke toko, kemudian melalukan pembelian. Adapun jenis-jenis display sebagai berikut; (1) Window Display. Memajang produk, gambar, kartu harga, simbol dan sebagainya di bagian depan toko yang disebut dengan etalase. Tujuan utama menerapkan window display adalah menimpulkan impulsive buying. (2) Interior Display. Memajang produk di dalam toko yang dapat dilakukan di lantai, meja, rak dan sebagainya. Interior display dibagi menjadi tiga dengan keunggulan dan kekurangan masing-masing; Open (yang dapat kita pegang langsung tanpa pramuniaga), Close (hanya dapat mengamatinya saja) dan Architectural Display (hanya menunjukkan gambarnya saja). (3) Exterior Display. Memajang produk diluar toko, seperti saat mengadakan midnight sale.

\section{Konsumen}

Istilah konsumen berasal dari kata consumer (Inggris-Amerika), atau consument/konsument (Belanda). Secara harafiah arti kata consumer adalah (lawan dari produsen) setiap orang yang menggunakan barang. Tujuan penggunaan barang dan jasa nanti menentukan termasuk konsumen kelompok mana pengguna tersebut. Begitu pula Kamus Bahasa Inggris-Indonesia memberi arti kata consumer bagi pemakai atau konsumen. Konsumen merupakan salah satu faktor lingkungan bisnis di luar kekuasaan manajemen perusahaan. Walaupun perusahaan dapat menentukan pilihan segmen pasar yang dilayani, mereka tetap tidak dapat menguasai khusus konsumen yang mempengaruhi kebutuhan (Sutojo, 2009).

Pembahasan mengenai konsumen tidak lepas dari perilakunya. Menurut Schiffman \& Kanuk (2010), perilaku konsumen adalah perilaku yang ditampilkan konsumen dalam mencari, membeli, menggunakan, mengevaluasi, dan membuang produk dan layanan yang mereka harapkan akan memuaskan kebutuhan mereka. Perilaku konsumen berfokus pada bagaimana konsumen individu dan keluarga atau rumah tangga membuat keputusan untuk menghabiskan 
sumber daya mereka yang tersedia (waktu, uang, usaha) pada barang-barang yang terkait dengan konsumsi. Termasuk apa yang mereka beli, mengapa membelinya, kapan mereka membelinya, di mana mereka membelinya, seberapa sering mereka membelinya, seberapa sering mereka menggunakannya, bagaimana mereka mengevaluasinya setelah pembelian, dampak evaluasi tersebut pada pembelian di masa depan dan bagaimana mereka membuangnya (Irwandy, Rachmawati, 2018).

\section{Masyarakat Konsumsi}

Baudrillard mengatakan bahwa menurut Campbell, Masyarakat konsumen merupakan masyarakat yang cenderung diorganisasikan diseputar konsumsi ketimbang produksi baik barang maupun jasa, sehingga membuat masyarakat akan cenderung menyamakan level konsumsi yang tinggi dengan kesuksesan sosial dan kebahagiaan personal sebagai salah satu tujuan hidupnya. Masyarakat konsumen sendiri akan merasa ketinggalan zaman jika masyarakat tidak membeli produk baru dari industri budaya yang telah dipersepsikan bagian dari identitas atau simbol status pada masyarakat postmodern. Hal tersebut telah dipengaruhi oleh tekanan kebutuhan yang terus menerus untuk menunjukan gaya hidup, dan tekanan perusahaan atau industri komersial yang terus memproduksi barang sesuai dengan perkembangan zaman yang semakin global (Baudrillard, 2018).

Menurut Marshall, kebutuhan itu saling tergantung satu sama lain dan rasional. Sedangkan Galbraith, berpendapat bahwa pemilihan-pemilihan dipaksakan lewat persuasi. Dari kedua pendapat ahli di atas di rangkum menjadi satu oleh Gervasi dalam buku Masyarakat Konsumsi yaitu, pilihan-pilihan tidak dibuat secara kebetulan, tetapi terkontrol secara sosial, dan menggambarkan model budaya di tengah budaya yang mereka buat (Baudrillard, 2018).

Menurut Baudrillard, kini logika konsumsi masyarakat bukan lagi berdasarkan use value atau exchange value melainkan hadir nilai baru yang disebut "symbolic value". Maksudnya, orang tidak lagi mengkonsumsi objek berdasarkan nilai tukar atau nilai guna, melainkan karena nilai tanda atau simbolis yang sifatnya abstrak dan terkonstruksi. Ini disebut dengan meta-konsumsi dimana untuk mengerti bahwa personalisasi pencarian status tingkat hidup ini didasarkan pada tanda-tanda, artinya tidak didasarkan pada objek atau barang itu sendiri, tetapi pada perbedaan-perbedaannya. Jadi, setiap individu dalam masyarakat konsumeris memiliki keinginan untuk terus melakukan pembedaan antara dirinya dengan orang lain. Individu akan terus mengkonsumsi produk-produk yang dianggap akan memberikan atau menaikkan status sosialnya, tanpa memikirkan apakah produk tersebut dibutuhkan atau tidak (Baudrillard, 2018).

Dapat disimpulkan bahwa konsumen tidak lagi melakukan konsumsi suatu objek atas dasar kebutuhan, tetapi untuk mendapatkan status sosial tertentu dari nilai tanda yang diberikan objek tersebut (Baudrillard, 2018)

\section{Media Massa}

Proses komunikasi pada hakikatnya adalah proses penyampaian pikiran atau perasaan. Pikiran bisa berupa gagasan, informasi, opini, dan lainnya. Sedangkan perasaan dapat berupa keyakinan, kepastian, keberanian, dan sebagainya yang timbul dari lubuk hati seseorang. Pada era modern seperti sekarang komunikasi massa yang paling populer adalah komunikasi massa melalui media internet atau yang sering kita sebut dengan online media. Menurut Cangara, komunikasi massa selalu melibatkan peran media atau alat atau sarana yang digunakan untuk menyampaikan pesan dari komunikator kepada khalayak. Pengertian media massa sendiri adalah alat yang digunakan untuk menyampaikan pesan dari sumber ke penerima dengan menggunakan alat-alat komunikasi mekanis, seperti surat kabar, film, radio, dan televisi. Dari penjelasan 
tersebut dapat disimpulkan bahwa media massa merupakan media yang digunakan dalam penyampaian pesan dari komunikator kepada penerima yang berjumlah besar secara bersamaan.

Media massa sangat berperan dalam perkembangan atau bahkan perubahan pola tingkah laku dari suatu masyarakat, oleh karena itu kedudukan media massa dalam masyarakat sangatlah penting. Dengan adanya media massa, masyarakat yang tadinya dapat dikatakan tidak beradab dapat menjadi masyarakat yang beradab. Hal itu disebabkan, karena media massa mempunyai jaringan yang luas dan bersifat masal sehingga masyarakat yang membaca tidak hanya orang-perorang tapi sudah mencakup jumlah puluhan, ratusan, bahkan ribuan pembaca (Hafied, 2007).

Seiring dengan perkembangan teknologi dan sosial budaya, telah berkembang media-media lain yang kemudian dikelompokkan ke dalam media massa seperti internet. New media atau media baru merupakan sarana perantara yang baru dilihat dari segi waktu, manfaat, produksi, dan distribusinya. Salah satu ciri yang menonjol adalah adanya interaksi antara manusia dengan komputer dan internet. Bentuknya beragam mulai dari web, blog, online social network, dan online forum (Ruben, Stewart, 2013). Tentunya media massa disini mempunyai fungsi untuk mempersuasi masyarakat atau konsumen untuk membeli produk yang dipasarkan, yang mungkin tadinya tidak butuh tetapi dikemas dengan sedemikian rupa agar dirasa butuh untuk dibeli.

\section{Media Sosial}

Sebuah konsep yang berkaitan dengan struktur sosial antara pelaku, sebagian besar individu, atau dalam organisasi, yang menunjukkan cara mereka saling terhubung melalui berbagai hubungan sosial seperti persahabatan, rekan kerja, atau hanya sekedar pertukaran informasi. Hubungan sosial dalam jaringan sering digambarkan dengan sebuah diagram yang didalamnya adalah titik pusat, sedangkan media adalah sebuah garis konektivitas sosial. Penjelasan tersebut senada dengan bahwa jaringan sosial dapat dipandang sebagai suatu sistem hubungan sosial yang ditandai dengan serangkaian informasi dan komunikasi dalam sosial media. Dengan demikian, satu sama lain bisa menciptakan jaringan sosial (Wasserman, Faust, 1994).

Jejaring sosial sekarang ini sudah menjadi suatu kebutuhan bagi setiap remaja ataupun orang dewasa. Jejaring sosial adalah tempat dimana kita mendapatkan teman baik di dalam maupun luar negeri. Karakteristik pada media sosial modern adalah sebagai berikut: (1) Transparansi: segala sesuatu tampak terbuka karena di dalamnya yang terdapat elemen dan materinya memang ditujukan untuk konsumsi publik atau sekelompok orang. (2) Dialog dan komunikasi: dalam suatu dialog akan terjalin suatu hubungan yang sepenuhnya berupa komunikasi, misalnya antara suatu brand dengan para konsumennya. (3) Jejaring relasi: hubungan antara elemen-elemen penyusun akan terjalin dan juga terdapat relasi yang akan terbentuk antara individu atau kelompok. (4) Multi opini: setiap individu akan berargumen dan setiap orang memiliki pandangan yang berbeda dan relatif, baik pandangan itu benar, salah atau berada dalam grey area, tergantung dalam wujud komunikasi sebagai medianya (Juju, Sulianta, 2010).

\section{Instagram}

Instagram berasal dari kata "instan" atau "insta", seperti kamera polaroid yang dulu lebih dikenal dengan "foto instan". Instagram juga dapat menampilkan fotofoto secara instan dalam tampilannya. Sedangkan untuk kata "gram" berasal dari kata "telegram", dimana cara kerja telegram adalah untuk mengirimkan informasi kepada orang lain dengan cepat. Begitu pula dengan Instagram yang dapat mengunggah foto dengan menggunakan jaringan internet, sehingga informasi yang disampaikan dapat diterima dengan cepat. Oleh karena itulah Instagram berasal dari kata "instan-telegram". Sehingga dapat 
disimpulkan bahwa Instagram merupakan layanan berbabsis internet dan jejaring sosial untuk berbagi informasi gambar atau foto maupun video (Juju, Sulianta, 2010).

Menurut Bambang, Instagram adalah sebuah aplikasi dari smartphone yang khusus untuk media sosial yang merupakan salah satu dari media digital yang mempunyai fungsi hampir sama dengan Twitter, namun perbedaannya terletak pada pengambilan foto dalam bentuk atau tempat untuk berbagi informasi terhadap penggunanya. Instagram juga dapat memberikan inspirasi bagi penggunanya dan juga dapat meningkatkan kreatifitas, karena Instagram mempunyai fitur yang dapat membuat foto menjadi lebih indah, lebih artistik dan menjadi lebih bagus (Atmoko, 2012). Mengingat bahwa saat ini terdapat 61 juta pengguna Instagram aktif di Indonesia dan angka tersebut terus bertambah dari harike hari (Kumparan, n.d).

\section{METODE PENELITIAN}

Metode penelitian yang digunakan dalam penelitian ini adalah kualitatif interpretatif dengan pendekatan postmodern Baudrillard. Penelitian kualitatif ini lebih memberikan gambaran mengenai fenomena berdasarkan perilaku komunikasi yang ada dalam penelitian yang dipaparkan dengan merujuk pada penggunaan media sosial Instagram sebagai medium display produk yang nantinya dikemas sedemikian rupa agar konsumen ingin membeli. Metode kualitatif dapat dieksplorasi dan dipahami maknanya oleh beberapa individu atau sekelompok orang yang dianggap berasal dari masalah sosial atau kemanusiaan (Cresswell, 2010). Mengeksplorasi seberapa besar peran media sosial Instagram menjadi display produk. Penelitian kualitatif bermaksud untuk memahami fenomena yang dialami oleh subjek penelitian, bisa berupa perilaku persepsi, motivasi, tindakan lain secara holistik, dan dengan deskripsi dalam bentuk kata-kata dan bahasa, pada suatu konteks khusus yang alamiah dengan memanfaatkan berbagai metode alamiah (Moelong, 2010).
Penelitian ini dilakukan pada akun Instagram Starbucks Indonesia periode Januari hingga Februari 2020. Pengumpulan data dilakukan dengan menggunakan observasi teks pada content Instagram Starbucks Indonesia (@Starbucks indonesia), wawancara semi terstruktur dan studi literatur pada website Starbucks Indonesia. Moment yang akan diobservasi adalah 'One For You, One To Share. \#SayItWithSbux'. Ini adalah promo yang dibuat oleh Starbucks khusus untuk menyambut hari kasih sayang atau yang biasa dikenal Valentine's Day. Observasi teks dilakukan dengan melihat seberapa banyak likes dan comment dalam foto atau video yang di upload oleh Starbucks Indonesia dan seberapa banyak yang menggunakan voucher promo pada tanggal 14 Februari 2020 khusus gerai Starbucks Mall Central Park. Dan melakukan observasi non partisipan untuk melihat keadaan pengunjung pada saat hari tersebut diadakan promosi tersebut. Studi literatur digunakan untuk lebih memperdalam teori yang digunakan agar tetap relevan pada pengaplikasian fenomena yang diteliti (Starbucks Indonesia).

Melalui kajian literatur, peneliti yang bersangkutan dapat menyatakan secara jelas mengapa masalah ini harus diteliti, baik dari segi subjek yang akan diteliti dan lingkungannya, maupun dari sisi hubungan penelitian tersebut dengan penelitian lain yang relevan. Disamping itu, kajian literatur juga bisa membantu peneliti mempertajam perumusan masalah dan tujuan penelitian serta kerangka berpikir. Kerangka berpikir membantu peneliti untuk melihat masalah yang diteliti, dan mengidentifikasi serta mengembangkan konsep yang nantinya akan membantu peneliti ditahap selanjutnya, yaitu perumusan hipotesis, penentuan metode penelitian, pengumpulan data, dan analisis data (Neuman, 2006).

Dalam penelitian ini hanya terdapat satu informan kunci yaitu Daru Darmawan yang pada hari itu bertugas sebagai PIC di gerai Starbucks Mall Central Park. Daru sudah bekerja selama dua tahun sebagai PIC 
gerai tersebut atau nama lainnya adalah store manager untuk Starbucks Mall Central Park. Sebelumnya beliau bekerja sebagai store manager untuk gerai Starbucks di Grand Indonesia. Penelitian ini hanya fokus pada gerai Starbucks Mall Central Park, LG floor.

Fokus penelitian pada penelitian ini adalah peneliti melihat media sosial Instagram Starbucks Indonesia sebagai display promosi yang ditinjau dari masyarakat konsumsi Jean P. Baudrillard. Media sosial di Instagram tersebut menjadi penyampai pesan yang bersifat persuasif bagi masyarakat yang mengikuti akun Instagram tersebut dan berdampak khususnya pada satu gerai Starbucks di Central Park Mall Lantai LG. Ketika Starbucks Indonesia mengeluarkan menu atau promosi baru di Instagram sudah dapat dipastikan bahwa hal tersebut sudah ada dan dapat dibeli diseluruh gerai Starbucks.

Teknik analisis data yang digunakan peneliti dari Miles dan Huberman; (1) Reduksi Data: reduksi data mengacu pada proses pemilihan, pemfokusan, penyederhanaan, pengabstrakan dan pembentukan data matang yang muncul dan penulisan catatan observasi. (2) Display data: kesimpulan informasi yang tertata yang mengizinkan penyusunan kesimpulan dan pengambilan tindakan. Display berguna untuk membantu memahami apa yang terjadi dan melakukan sesuatu analisis atau tindakan selanjutnya berdasarkan pemahaman. (3) Penyusunan kesimpulan; peneliti menyusun kesimpulan secara singkat dan jelas (Miles, Huberman, 2014).

Untuk menguji validitas, peneliti mengacu pada teori dan buku untuk mendalami dan menjabarkan konsep teori ke dalam fenomena yang terjadi yaitu teknik Triangulasi. Triangulasi adalah pemikiran bahwa kesimpulan suatu studi memiliki validitas yang lebih banyak apabila penelliti menggunakan lebih dari satu metode analisa data. Peneliti menggunakan tiga langkah, yaitu; (1) Triangulasi sumber data, yang dilakukan dengan cara mencari data dengan orang yang terlibat langsung dengan objek penelitian. (2) Triangulasi metode. Pengumpulan data dilakukan dengan menggunakan berbagai macam metode pengumpulan data yaitu oberservasi non partisipan dan studi literatur. (3) Triangulasi teori, dilakukan dengan cara mengkaji berbagai teori relevan (Endraswara, 2006).

Metode penelitian yang digunakan dalam penelitian ini adalah kualitatif interpretatif dengan pendekatan postmodern Baudrillard. Penelitian kualitatif ini lebih memberikan gambaran mengenai fenomena berdasarkan perilaku komunikasi yang ada dalam penelitian yang dipaparkan dengan merujuk pada penggunaan media sosial Instagram sebagai medium display produk yang nantinya dikemas sedemikian rupa agar konsumen ingin membeli. Metode kualitatif dapat dieksplorasi dan dipahami maknanya oleh beberapa individu atau sekelompok orang yang dianggap berasal dari masalah sosial atau kemanusiaan (Cresswell, 2010). Mengeksplorasi seberapa besar peran media sosial Instagram menjadi display produk. Penelitian kualitatif bermaksud untuk memahami fenomena yang dialami oleh subjek penelitian, bisa berupa perilaku persepsi, motivasi, tindakan lain secara holistik, dan dengan deskripsi dalam bentuk kata-kata dan bahasa, pada suatu konteks khusus yang alamiah dengan memanfaatkan berbagai metode alamiah (Moelong, 2010).

Penelitian ini dilakukan pada akun Instagram Starbucks Indonesia periode Januari hingga Februari 2020. Pengumpulan data dilakukan dengan menggunakan observasi teks pada content Instagram Starbucks Indonesia (@Starbucks indonesia), wawancara semi terstruktur dan studi literatur pada website Starbucks Indonesia. Moment yang akan diobservasi adalah 'One For You, One To Share. \#SayItWithSbux'. Ini adalah promo yang dibuat oleh Starbucks khusus untuk menyambut hari kasih sayang atau yang

ISSN 2338 - 0861 (cetak); e-ISSN 2621 - 8712 (online)

website : http://spektrum.stikosa-aws.ac.id 
biasa dikenal Valentine's Day. Observasi teks dilakukan dengan melihat seberapa banyak likes dan comment dalam foto atau video yang di upload oleh Starbucks Indonesia dan seberapa banyak yang menggunakan voucher promo pada tanggal 14 Februari 2020 khusus gerai Starbucks Mall Central Park. Dan melakukan observasi non partisipan untuk melihat keadaan pengunjung pada saat hari tersebut diadakan promosi tersebut. Studi literatur digunakan untuk lebih memperdalam teori yang digunakan agar tetap relevan pada pengaplikasian fenomena yang diteliti (Starbucks Indonesia).

Melalui kajian literatur, peneliti yang bersangkutan dapat menyatakan secara jelas mengapa masalah ini harus diteliti, baik dari segi subjek yang akan diteliti dan lingkungannya, maupun dari sisi hubungan penelitian tersebut dengan penelitian lain yang relevan. Disamping itu, kajian literatur juga bisa membantu peneliti mempertajam perumusan masalah dan tujuan penelitian serta kerangka berpikir. Kerangka berpikir membantu peneliti untuk melihat masalah yang diteliti, dan mengidentifikasi serta mengembangkan konsep yang nantinya akan membantu peneliti ditahap selanjutnya, yaitu perumusan hipotesis, penentuan metode penelitian, pengumpulan data, dan analisis data (Neuman, 2006).

Dalam penelitian ini hanya terdapat satu informan kunci yaitu Daru Darmawan yang pada hari itu bertugas sebagai PIC di gerai Starbucks Central Park Mall. Daru sudah bekerja selama dua tahun sebagai PIC gerai tersebut atau nama lainnya adalah store manager untuk Starbucks Central Park Mall. Sebelumnya beliau bekerja sebagai store manager untuk gerai Starbucks di Grand Indonesia. Penelitian ini hanya fokus pada gerai Starbucks Mall Central Park, LG floor.

Fokus penelitian pada penelitian ini adalah peneliti melihat media sosial Instagram Starbucks Indonesia sebagai display promosi yang ditinjau dari masyarakat konsumsi Jean P. Baudrillard. Media sosial di Instagram tersebut menjadi penyampai pesan yang bersifat persuasif bagi masyarakat yang mengikuti akun Instagram tersebut dan berdampak khususnya pada satu gerai Starbucks di Central Park Mall Lantai LG. Ketika Starbucks Indonesia mengeluarkan menu atau promosi baru di Instagram sudah dapat dipastikan bahwa hal tersebut sudah ada dan dapat dibeli diseluruh gerai Starbucks .

Teknik analisis data yang digunakan peneliti dari Miles dan Huberman; (1) Reduksi Data: reduksi data mengacu pada proses pemilihan, pemfokusan, penyederhanaan, pengabstrakan dan pembentukan data matang yang muncul dan penulisan catatan observasi. (2) Display data: kesimpulan informasi yang tertata yang mengizinkan penyusunan kesimpulan dan pengambilan tindakan. Display berguna untuk membantu memahami apa yang terjadi dan melakukan sesuatu analisis atau tindakan selanjutnya berdasarkan pemahaman. (3) Penyusunan kesimpulan; peneliti menyusun kesimpulan secara singkat dan jelas (Miles, Huberman, 2014).

Untuk menguji validitas, peneliti mengacu pada teori dan buku untuk mendalami dan menjabarkan konsep teori ke dalam fenomena yang terjadi yaitu teknik Triangulasi. Triangulasi adalah pemikiran bahwa kesimpulan suatu studi memiliki validitas yang lebih banyak apabila penelliti menggunakan lebih dari satu metode analisa data. Peneliti menggunakan tiga langkah, yaitu; (1) Triangulasi sumber data, yang dilakukan dengan cara mencari data dengan orang yang terlibat langsung dengan objek penelitian. (2) Triangulasi metode. Pengumpulan data dilakukan dengan menggunakan berbagai macam metode pengumpulan data yaitu oberservasi non partisipan dan studi literatur. (3) Triangulasi teori, dilakukan dengan cara mengkaji berbagai teori relevan (Endraswara, 2006). 


\section{HASIL DAN PEMBAHASAN}

\section{Instagram sebagai Display}

Di era globalisasi ini, teknologi komunikasi berkembang dengan pesat, begitu juga dengan media sosial yang menjadi salah satu media penyampai pesan yang cepat. Tak bisa dipungkiri lagi bahwa media adalah salah satu sarana yang penting dalam perkembangan saat ini. Mengambil kontribusi yang cukup besar dalam penyebaran pesan yang terjadi karena ditujukan kepada khalayak banyak dan tak terbatas untuk diakses. Walaupun media cetak online tetap berjalan namun ada satu media, yaitu media baru yang maju lebih pesat dibandingkan yang lain karena memberikan kemudahan tersendiri.

Media baru yang saat ini digunakan secara aktif adalah internet, semua dengan mudah ditemukan. Internet memberikan kita akses tak terbatas untuk membuka dan menggunakan aplikasi seperti Instagram yang awalnya hanya untuk kepentingan pribadi namun sekarang sudah beralih fungsi menjadi display untuk mempromosikan produk yang ditawarkan atau dijual. Tentu hal ini sangat berpengaruh pada gaya hidup masyarakat di era modern saat ini.

Masyarakat melihat akun media sosial Instagram yang dibuat oleh Starbucks Indonesia menarik dan mempunyai banyak manfaat karena banyak penawaran dan infromasi menarik yang hadir jika mereka mengikutinya. Dari kasus yang diteliti, gerai Starbucks Indonesia sangat ramai akan pembeli adalah disaat memperingati hari tertentu salah satunya bulan Februari 2020 lalu, Starbucks Indonesia mengadakan promo Valentine's Day atau yang dikenal sebagai hari kasih sayang dengan kupon promo 'One For You, One To Share. \#SayItWithSbux". Kupon promo ini bisa didapatkan dengan klik link yang tertera di bio instagram Starbucks Indonesia yang nantinya akan terhubung langsung dengan web Starbucks yang bisa ditukarkan kepada kasir saat membeli minuman. Tentunya saat moment seperti ini Starbucks juga mengeluarkan official merchandice khusus hari kasih sayang berupa tumbler dan
Starbucks card limited edition dengan penawaran khusus menggunakan kartu maupun aplikasi digital Starbucks ID.

Tentu promo ini sudah dipersiapkan Starbucks dari akhir Januari menjelang bulan Februari, agar orang-orang tau bahwa akan ada promo spesial pada tanggal 14 Februari nanti. Hal ini sempat membuat gerai Starbucks khususnya di Mall Central Park Lantai LG, mengalami antrian yang mengular, dan konsumen yang membeli sangat membludak. Mereka yang datang mau tidak mau harus mengajak teman, keluarga, ataupun pacar untuk ikut berpartisipasi dalam promosi yang dilakukan oleh Starbucks Indonesia dengan pembelian minimal dua minuman yang ditukarkan menggunakan kupon digital. Menurut Daru Darmawan selaku General Store Manager di gerai Starbucks Mall Central Park pada saat itu, setidaknya ada 3500 kupon yang ditukarkan pada hari itu, yang berarti sudah ada 7000 minuman yang diproduksi hari itu diluar pemesanan reguler yang ada.

Pada hari itu juga, jika masih ada yang belum mengetahui promo maka barista atau kasir akan menawarkan promo yang ada pada hari itu sehingga banyak orang yang tadinya tidak memakai promo menjadi memakai promo yang berlaku. Hal ini efektif digunakan disaat-saat memperingati hari-hari tertentu saja seperti saat ini yaitu hari kasih sayang. Bagi mereka yang ini memberikan kejutan untuk pasangannya, Starbucks menyediakan jasa untuk menuliskan pesan singkat untuk orang terkasihnya digelas minumannya. Fenomena ini ditinjau dari teori masyarakat konsumsi Baudrillard, bahwa mereka yang membeli barang atau produk tersebut sudah tidak tergantung oleh kebutuhan tetapi selalu berdasarkan suatu hal yaitu keinginan. Hal-hal yang mengikuti adalah seperti pemikiran jika ada promo kita bisa membeli barang tersebut dalam hal ini minuman dengan tujuan mengikuti gelombang yang sedang ramai pada saat itu. Momentum peringatan ini juga dijadikan ajang untuk saling memperlihatkan minuman favorit mereka yang dibeli di 
Starbcuks yang menujukkan bahwa mereka mampu untuk membeli minuman sekelas Starbucks padahal saat itu sedang diadakan promosi harga.

Dari hasil tersebut mengatakan bahwa media sosial Instagram Starbucks Indonesia sudah mencangkup empat karakteristik media sosial yaitu; 1) transparan karena sudah semua konten sudah dibuat untuk umum dan tidak terbatas akses, waktu dan ruang; 2) dialog dan komunikasi terjalin dua arah dengan melihat kolom komentar, likes dan juga tag yang dilakukan untuk konten instagram stories maupun direct message yang masuk, tentu dengan penukaran kupon promo hari itu; 3) jejaring relasi tentu bisa berupa repost setiap konten customer yang mention Starbucks Indonesia pada hari itu; 4) multi opini disini adalah adanya feedback yang bisa menjadi masukan diterima dengan terbuka dan menjadi evaluasi, salah satu bentuknya adalah menggunakan survey random setiap 1000 customer yang datang langsung dilakukan oleh General Store Manager.

Peneliti juga melakukan teknik analisa dengan reduksi data dari segala metode yang peneliti gunakan, yaitu hasil literasi dari instagram Starbucks Indonesia dari posting-an beranda maupun instastories, likes and comments, observasi gerai Starbucks Mall Central Park, lantai LG pada tanggal 14 Februari 2020 yang diakhiri dengan pengumpulan data dari store manager yaitu Daru Darmawan pada hari itu untuk mengetahui berapa banyak kupon yang berhasil ditukarkan dan berapa banyak pengunjung yang data hari itu dalam bentuk wawancara pribadi semi terstruktur. Kupon yang berhasil di tukarkan sebesar 3500 kupon dengan data seluruh pengunjung hari itu tanpa terkecuali adalah mendekati angka 7000 pengunjung yang dine-in maupun take away (Darmawan, wawancara pribadi, 2020). Semua data ini diolah menjadi satu catatan observasi.

Peneliti juga melakukan display data daalam teknik analisa untuk menyusun tindakan apa saja yang harus dilakukna.
Peneliti dari awal sudah melakukan pencarian sumber dari berbagai website maupun instagram resmi dari Starbukcs itu sendiri dan selanjutnya peneliti mendatangi langsung tempat penelitian dan mewawancari General Store Manager gerai tersebut yaitu Daru Darmawan agar dapat mendapatkan informasi lebih dalam lagi perihal yang diteliti. Analisis terakhir yang digunakan oleh peneliti adalah penarikan kesimpulan yang nantinya akan memfokuskan kepada hasil yang akan didapat nantinya.

Dalam promo 'One For You, One For Share. \#SayItWithSbux' ini Starbucks berhasil menjadikan instagram -nya sebagai media display untuk menarik perhatian dan mempersuasi khalayak banyak, minimal mempersuasi followersnya terlebih dahulu. Starbucks menjadikan hari kasih sayang menjadi hari yang spesial dengan menjual produk special edition selama bulan Februari. Banyak customer yang tadinya tidak ingin membeli Starbucks menjadi mampir ke gerai Starbucks terdekat dikarenakan promo yang ada dan dengan rela mengunggahnya ke media sosial milik pribadi.

Dalam hal ini peneliti menemukan bahwa ada dua faktor yang membuat orang tertarik untuk membeli produk Starbucks ini, yaitu: 1) karena sedang dalam masa promosi, sehingga harganya jauh lebih murah dari biasanya dengan kualitas minuman yang sama. 2) pesan yang disampaikan dalam platform instagram milik Starbucks menarik sehingga membuat orang ingin datang. Harga murah bisa membuat target untuk bertindak langsung membeli karena harga yang sedang turun tanpa memikirkan bahwa sebetulnya belum butuh barang atau produk tersebut. Jika karena gambar, video, atau teks yang diunggah pada Instagram berarti ada ketertarikan sendiri dengan isi pada hal yang diunggah tersebut, dari kata-katanya, gambarnya, permainan warna maupun penawarannya. Hal ini selaras dengan teori dari Baudrillard bahwa nilai dari sebuah simbol diterapkan dalam hal ini. Mengonsumsi suatu barang karena tanda 
dan simbolis yang sidatnya abstrak dan konstruksi, bukan karena nilai guna atau tukarnya lagi. Nilai simbol dalam penelitian ini adalah jika kita membeli produk Starbucks dengan ciri khas logonya dan promo menariknya maka orang akan berpikir bahwa status orang tersebut patut dipertimbangkan (Baudrillard, 2018).

Dilihat dari fenomena yang ada, tingkat konsumsi masyarakat dipengaruhi oleh display yang dilihat dari media sosial yang mereka ikuti ataupun lingkungan sekitar yang mempengaruhi keputusan pembelian serta promo yang ditawarkan. Tadinya orang tidak tahu menjadi tahu, yang tidak ingin membeli menjadi membeli, yang tidak tertarik menjadi ingin mencoba dan membeli produk tersebut.

\section{Stimulus Display Instagram Dalam Masyarakat Konsumsi}

Masyarakat menjadi konsumtif karena dipengaruhi oleh adanya stimulus menarik dalam bentuk promosi yang ditawarkan oleh Starbucks yang disebarkan melalui media sosial Instagram. Promo ini dikemas menjadi suatu hal yang identik dengan perayaan hari kasih sayang atau Valentine's Day yang didukung dengan mengeluarkannya edisi khusus untuk merchandise serta promo menari yang hanya berlaku di hari itu saja dan berlakuk di semua gerai Starbucks yang ada di Indonesia tanggal 14 Februari 2020 khusunya pada gerai Mall Central Park Lantai LG. Penawaran dengan label 'Limited Edition" menjadikannya efektif karena sifat masyarakat post modern menurut Baudrillard (2018) terletak pada perbedaan dari produk yang ditawarkan atau dikonsumsi, menunjukkan hanya beberapa orang saja yang memilikinya dalam jangka waktu tertentu dan tidak diproduksi sebanyak produk reguler sehingga meningkatkan status sosial orang tersebut saat itu.

Starbucks juga melakukan repost untuk mereka yang tag akun instagram Starbucks Indonesia dengan hastag SayItWithSbux yang banjir akan kata-kata manis dari barista atau bahkan pesan sayang bagi mereka yang diberi kejutan melalui Starbucks ini, dengan kata lain mereka mempromosikan Starbucks secara cuma-cuma melalui media sosial pribadi mereka dan dengan senang hati seakan semua yang mengikutinya harus tau apa yang sedang diminum atau dikonsumsi. Tadinya mungkin orang tidak tahu ada promo tersebut, sehingga menjadi tahu, yang tadinya belum mengikuti akun instagram Starbucks menjadi bagian dari followers Starbucks . Peran instagram sebagai media display cukup signifikan untuk menyebarluaskan informasi tanpa mengeluarkan biaya mahal, dan tidak terbatas ruang dan waktu yang ada. Hal ini selaras dengan fungsi dari media baru yaitu internet adalah menyebarkan informasi secara luas, aktual dan bisa diakses siapapun.

Masyarakat akan menjadi lebih konsumtif ketika melihat media sosial dipenuhi dengan pendapat positif atau feedback dari orang lain yang sudah pernah mencoba dan mempertimbangan keputusan pembelian. Dalam hal ini menunjukan isi pesan di gelas minuman ataupun memakai \#SayItWithSbux. Format display yang diatur sedemikian rupa oleh akun Starbucks Indonesia menjadikannya menarik untuk dilihat. Apalagi mendapatkan testimonial langsung dari orang terdekat yang berpengaruh dan berperan penting dalam hidup mereka. Maka dari itu masyarakat konsumsi tidak luput dari lingkungan dimana mereka beraktivitas dan ditempatkan, karena kebiasaan yang dilakukan oleh mayoritas di lingkungannya tersebut akan dilihat sebagai gaya hidup.

Peneliti melihat bahwa dari catatan observasi yang didapatkan dan diolah betul adanya pengaruh media sosial yang sangat besar pada keputusan pembelian masyarakat terhadap pembelian suatu produk tapi tidak dipungkiri juga bahwa faktor promosi yang dilakukan juga menjadi salah satu faktor besar yang patut dikaji lebih dalam lagi. Teori yang relevan pada penelitian ini adalah masyarakat konsumsi dari Baudrillard yang berfokus kepada nilai suatu simbol yang menjadi trend bagi masyarakat post-modern saat ini yang

ISSN 2338 - 0861 (cetak); e-ISSN 2621 - 8712 (online)

website : http://spektrum.stikosa-aws.ac.id 
menjadikan sebuah keinginan sebagai kebutuhan hanya untuk menaikan status sosial. Peneliti juga beranggapan bahwa jika Starbucks Indonesia melakukan promosi dan dikemas spesial seperti ini akan menjadi suatu keuntungan bagi Starbucks .

\section{KESIMPULAN}

Hasil penelitian menunjukkan bahwa display sebuah media sosial dapat menjadikan motivasi seseorang untuk membeli sesuatu. Perubahan yang terjadi adalah masyarakat tidak lagi membeli dan mengonsumsi produk tersebut karena nilai guna atau tukar suatu barang lagi akan tetapi nilai simbol yang dikonsumsi, dalam hal ini Starbucks. Sifat masyarakat post modern yang mengikuti arus untuk terlihat up-to-date dengan yang lainnya, dan membeli atau mengkonsumsi barang karena dibutuhkan melainkan karena trend untuk meningkatkan status sosial.

Adapun saran yang diberikan oleh peneliti untuk Starbucks Indonesia, masyarakat kita kini memang sudah menjadi masyarakat yang konsumtif apalagi dengan adanya perkembangan teknologi yang memudahkan kita mendapat informasi, maka untuk itu media sosial instagram adalah wadah yang tepat untuk melakukan promosi dan berinteraksi dengan customer. Adapun saran akademisnya adalah dapat diperdalam untuk penelitian loyal customer yang menjadi potensi besar dalam menjalankannya. Memperdalam makna dibalik simbol Starbucks yang menjadi daya tarik tersendiri dan patut dijadikan bahan kajian selanjutnya.

\section{DAFTAR PUSTAKA}

Atmoko, D. B. (2012). Instagram Handbook Tips Fotografi Ponsel. Indonesia, Jakarta: Media Kita.

Baudrillard, Jean. (2018). Masyarakat Konsumsi, jilid kedelapan. Indonesia, Yogyakarta: Kreasi Wacana Offset.
Buchari, Alma. (2007). Manajemen Pemasaran dan Pemasaran Jasa. Indonesia, Bandung: CV Alfabeta.

Cangara, Hafied. (2007). Pengantar ilmu komunikasi. Indonesia, Jakarta: PT Raja Grafindo Persada.

Cresswell, J. W. (2010). Research design: pendekatan kualitatif, kuantitatif, dan mixed. Indonesia, Yogyakarta: PT Pustaka Pelajar.

Darmawan, D. (2020, 14 February). Personal Interview.

Endraswara. (2006). Metode, Teori, Teknik, Penelitian Kebudayaan: Ideologi, Epistemologi dan Aplikasi. Yogyakarta. Pustaka Widyatama.

Irwandy, D. \& Rachmawati, D. (2018). Penerapan Elaboration Likelihood Theory Dalam

Mempengaruhi Konsumen Pada Pemilihan Produk Telepon Genggam. Prosiding Konferensi Nasional Penelitian \& Pengabdian Masyarakat Bidang Komunikasi 2018, 17(2). ISSN: 14127873

Juju dan Sulianta, F. (2010). Branding promotion with social networks. Indonesia, Jakarta: PT Elex Media Komputindo.

Kumparan. (2019, December 24). Jumlah Pengguna Instagram Di Indonesia Capai 61 Juta. Kumparan TECH. Diakses dari https://kumparan.com/kumparantec h/jumlah-pengguna-instagram-diindonesia-capai-61-juta1sVVLzdQO0T

Maslow, A. H. (1991). Motivasi dan Kepribadian (Teori Motivasi dengan Pendekatan Hierarki Kebutuhan Manusia). Indonesia, Jakarta: PT PBP.

Miles, M.B, Huberman, A.M, dan Saldana, J. (2014). Qualitative Data Analysis, A Methods Sourcebook, Edition 3. USA: Sage Publications. Terjemahan Tjetjep Rohidi. Jakarta: UIP.

Moelong, L. A. (2010). Metodologi Penelitian Kualitatif. Indonesia, Bandung: PT Remaja Rosdakarya. 
Neuman, W. (2006). Social Research Methods Qualitative and Quantitative, Sixth Edition. America.

Putlia, G. (2018). Konsumerisme Mahasiswa Terhadap Starbucks Coffee Dalam Kerangka Teori Fetisisme Komoditas Dan Motivasi Hedonis. National Conference of Creative Industry: Susitanable Tourism Industry for Economic Development. E-ISSN: 26227436

Satvikadewi, A. A. I., \& Kusumaningrum, H. (2019). Profil Psikografis \& Penggunaan Media pada Kelompok Milenial Pengunjung Kebun Binatang Surabaya. Jurnal Spektrum Komunikasi, 7(2), 15-28. https://doi.org/10.37826/spektrum.v $\underline{7 \mathrm{i} 2.32}$

Solikatun, Drajat Tri Kartono, Argyo Demartoto. (2015). Perilaku Konsumsi Kopi Sebagai Budaya Konsumsi: Studi Fenomenologi Pada Peminum Kopi di Kedai Kopi Kota Semarang. Jurnal Analisa Sosiologi, $4(1), 60-74$.
Sophia dan Syihabudin. (2008). Manajemen Bisnis Ritel. Indonesia, Yogyakarta: Andi Offset.

Starbucks Coffee. (n.d). Starbucks in Indonesia. Diperoleh 21 Januari 2020, from http://www.Starbucks co.id/about-us

Starbucks Indonesia. (n.d). Starbucks Indonesia Monday Treats. Diperoleh 15 Februari 2020, from https://www.instagram.com/Starbuc ks indonesia/

Starbucks Indonesia. (n.d). Post Starbuck Indonesia. Diperoleh 14 Februari 2020, from

https://www.instagram.com/p/B8hzvIJnPt M/?utm_source=ig_web_copy_link

Starbucks Indonesia [@Starbucks indonesia]. (n.d). Post Starbucks Indonesia. Diperoleh 15 Februari 2020, from https://www.instagram.com/p/B8hz vIJnPtM/?utm source=ig web copy li $\underline{\mathrm{nk}}$

Sutojo, S. (2009). Manajemen Pemasaran. Indonesia, Jakarta: PT Damar Mulia Pustaka. 